\title{
Assessment of Concentration and Variations Due to Seasonal Effect on the Presence of Heavy Metals in the Water of Upper Lake, Bhopal
}

\author{
RANJANA TALWAR*, SHWETA AGRAWAL ${ }^{1}$, AVINASH BAJPAI ${ }^{2}$ and SUMAN MALIK ${ }^{3}$ \\ *Sadhu Vaswani College, Bairagarh, Bhopal, Madhya Pradesh, India. \\ ${ }^{1}$ Department of Life Sciences, Extol Institute of Management, Bhopal, India. \\ ${ }^{2}$ Makhanlal University, Bhopal, Madhya Pradesh, India. \\ ${ }^{3}$ Sadhu Vaswani College, Bairagarh, Madhya Pradesh, India. \\ http://dx.doi.org/10.12944/CWE.9.2.24
}

(Received: March 30, 2014; Accepted: May 14, 2014)

\begin{abstract}
Water is the most precious gift of nature and is a valued natural resource for the existence of living beings. Management of this natural resource is thus of utmost importance. The present study was carried out to determine the presence of a few heavy metals viz, lead, chromium, copper and mercury in the various samples of Upper Lake, Bhopal. The samples were analyzed during both the pre-monsoon and the post-monsoon season. From the observations it was concluded that a general increase in the concentration was observed in the post monsoon season due to surface runoff coming into the lake water in the rainy season.
\end{abstract}

Key words: Heavy metals, Management, Surface runoff, Post - monsoon.

\section{INTRODUCTION}

Water supports life on earth and is an essential commodity for survival of mankind and other living organisms. The development and growth of a nation is closely related to its water resources. When effectively harnessed, the potential for water resources can be enormous. But today, ignoring all these facts, man is indiscriminately polluting water and unknowingly provoking the nature for complex situations.

Bhopal, the capital city of Madhya Pradesh and the city of lakes is situated in the heart of India. It is facilitated with large number of water bodies in and around it. Upper lake, the biggest lake of Bhopal is the chief source of potable water for the residents of the city. The lake was created by Raja Bhoj in $11^{\text {th }}$ century by construction of an earthen dam across the Kolans river, a rain fed tributary of the Betwa river. The lake has a large catchment area of 361 sq.km and at present water spread area is $36 \mathrm{sq} . \mathrm{km}$ at full tank level. Bhopal is fast developing in all directions and fringe areas are converting into a part of urban development at a faster pace rapidly. The increased anthropogenic activities and urbanization in the catchment have caused an increased inflow of the silt, untreated domestic sewage from the nearby areas, nutrients, pesticides and other agricultural wastes from the rural areas, industrial wastes from the urban areas and an overall deterioration of the water quality.

Heavy metals are the pillars of all major civilizations. They are natural components of the Earth's crust. They cannot be degraded or destroyed. Today, contamination of water by toxic heavy metals in the form of wastes effluents from industries is a worldwide environmental problem. To a small extent they enter our bodies via food, drinking water and air. As trace elements, some heavy metals (e.g. lead, chromium, copper, mercury, manganese, selenium, zinc etc) are essential to maintain the metabolism of the human body. However, at higher concentrations 
they can lead to poisoning. Heavy metal poisoning could result, for instance, from drinking-water contamination (e.g. lead pipes), high ambient air concentrations near emission sources, from domestic sewage discharge, street dust, land runoff, fossil fuel burning or intake via the food chain. Large amounts of heavy metals may cause acute or chronic toxicity, upsetting the biological functions, causing deformity and even death in the end. Mukherjee A. (2005) stated that the biodegradable matter after decomposition recycles to the system while no biodegradable substances form sediments. The non bio-accumulation of heavy metal in biological system transfers the toxic element from producer to consumer level, which can be a future health hazard.

\section{METHOD AND MATERIALS}

The present study was conducted to evaluate the status of water quality of Upper Lake, Bhopal specifically in terms of determination of the concentration of a few selected heavy metals namely, Lead, Chromium, Copper and Mercury. For the study water samples were collected from various sampling sites of the Upper Lake in plastic cans. The heavy metals were preserved by adding $5 \mathrm{ml}$ of $1 \mathrm{~N} \mathrm{HNO}_{3}$ in one litre of sample, maintaining the $\mathrm{pH}$ to below 4.0. The samples were then transported to the laboratory for analysis of selective heavy metals following the standard procedure given by APHA using Atomic Absorption spectrophotometer.

\section{Description of Sampling Stations}

The sampling stations selected for the study were as under:

\section{S1 - Sampling station near Bairagrah Kalan}

This station of the Upper Lake is near Bairagarh and Sehore nalla and it is more polluted due to substantial inflow of domestic sewage.

\section{S2 - Sampling station near Kohefiza}

There are more than 6,000 accommodations in Koh-e-Fiza. All waste from these residences goes to the upper lake.

\section{S3 - Sampling station near Gandhi Medical College}

GMC is located in Fatehgarh area on
Sultania Road in Bhopal, Madhya Pradesh. The college stands tall on the ground where once Fatehgarh Fort stood. It is adjacent to VIP Road, which is a major tourist attraction due to a beautiful scene of the Upper Lake. Under Bhoj Wetland project due to diversion of Nalla the entry of silt load and hospital wastes into the lake has been prevented.

\section{S4 - Sampling station near Lake View}

This station of the Upper Lake is a site of recreational importance. The tourists get attracted to its scenic beauty.

\section{S5 - Sampling station near Prempura}

This sampling station of Upper lake is majorly affected by bathing and religious activities such as that of idol immersion.

\section{S6 - Sampling station near Kotra Nallah}

This station receives main untreated drainage from Kotra. It is the confluence point of drainage nalla from charimli area behind Kotra.

\section{S7 - Sampling station near Kaliasote}

This sampling station is situated near the Kaliasote dam and also has agricultural practices going on in the catchment area.

\section{RESULT AND DISCUSSION}

The observations of the current study can be summarized as follows:

\section{Lead}

Lead occurs naturally in the environment. However, most lead concentrations that are found in the environment are a result of human activities. Lead is used in leaded pipes, car batteries, ceramic glazes, screen of computers, in paints, enamels etc. Idol immersion is a common religious practice in India during Ganesh Visarjan and Durga Pooja. These idols are decorated with paints which consist of a considerable quantity of lead. The results have also supported the fact that the concentration of lead in the water samples increases after idol immersions ie during the post - monsoon period. The highest concentration of lead ie of $3.70 \mathrm{ppm}$ was observed at S5 station during the post monsoon period. Anju Vyas et. al. (2007) have also observed that lead concentration has increased many folds in the 
waters of Upper Lake, Bhopal due to idol immersion. Jaswant Singh et. al. (2012) Studied seasonal variations of heavy metal concentrations in water of Ramgarh lake, Gorakhpur and found that in all the seasons only the concentration of lead was found to be beyond limits $(0.1 \mathrm{mg} / \mathrm{tr})$. He also reported higher concentration of heavy metals in the pre monsoon season and a lower concentration in the post - monsoon season due to the dilution factor.

\section{Copper}

Copper is a widely used metal employed in many fields like transportation, manufacturing currency, electricity, construction and agricultural fields. It normally occurs in drinking water from copper pipes, as well as from additives designed to control algal growth. It is an essential component of key metalloenzyme that maintains the vascular and nervous system, but its high doses can cause anemia, liver and kidney damage, and stomach and intestinal irritation. During the present investigation, highest concentration of copper of $3.30 \mathrm{ppm}$ was observed at S2 station during the post monsoon period while the minimum concentration was observed at $\mathbf{S} 5$ station during the pre monsoon period. Anilava Kaviraj et. al. (1999) during his investigation discovered that the concentration of Cadmium, Zinc and Copper in water, sediment and fish of four perennial ponds of an industrial town showed an increased concentration during the summer and diluted concentration during monsoon. These metals were found to concentrate in sediment at much higher rate. Namdev et. al. (2011b) studied accumulation of micronutrients especially $\mathrm{Zn}, \mathrm{Cu}, \mathrm{Mn}$ and $\mathrm{Mo}$ and concluded that higher concentrations of these heavy metals were found higher near the station where chemical fertilizers are being used in the catchment area.

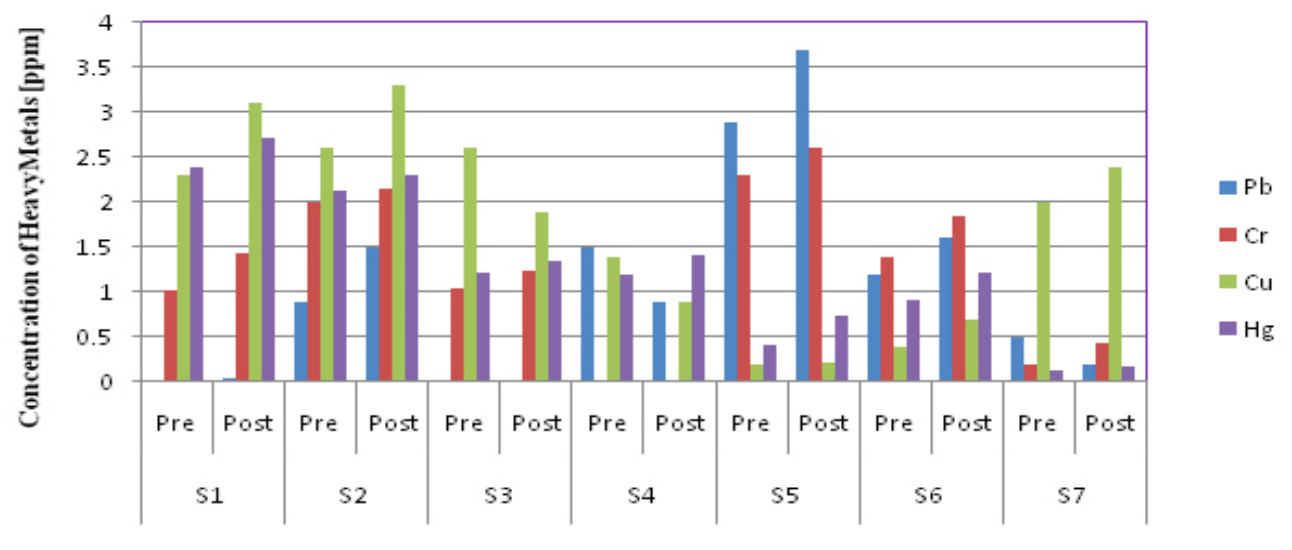

Sampling Stations

Fig. 1: Varaiation of lead, copper, chromium and mercury at different sampling stations of upper lake, bhopal

Table 1: Variation of $\mathrm{Pb}, \mathrm{Cu}, \mathrm{Cr} \& \mathrm{Hg}$ at different sampling stations of Upper Lake, Bhopal

\begin{tabular}{|c|c|c|c|c|c|c|c|c|}
\hline \multirow[b]{2}{*}{$\begin{array}{l}\text { Sampling } \\
\text { stations }\end{array}$} & \multicolumn{2}{|r|}{$\mathrm{Pb}$} & \multicolumn{2}{|r|}{$\mathrm{Cr}$} & \multicolumn{2}{|c|}{$\mathrm{Cu}$} & \multicolumn{2}{|c|}{$\mathrm{Hg}$} \\
\hline & $\begin{array}{l}\text { Pre } \\
\text { monsoon }\end{array}$ & $\begin{array}{c}\text { Post } \\
\text { monsoon }\end{array}$ & $\begin{array}{c}\text { Pre } \\
\text { monsoon }\end{array}$ & $\begin{array}{c}\text { Post } \\
\text { monsoon }\end{array}$ & $\begin{array}{c}\text { Pre } \\
\text { monsoon }\end{array}$ & $\begin{array}{c}\text { Post } \\
\text { monsoon }\end{array}$ & $\begin{array}{c}\text { Pre } \\
\text { monsoon }\end{array}$ & $\begin{array}{c}\text { Post } \\
\text { monsoon }\end{array}$ \\
\hline S1 & 0.02 & 0.05 & 1.02 & 1.44 & 2.30 & 3.10 & 2.40 & 2.71 \\
\hline S2 & 0.90 & 1.50 & 2.01 & 2.15 & 2.60 & 3.30 & 2.13 & 2.31 \\
\hline S3 & 0.02 & 0.02 & 1.04 & 1.23 & 2.60 & 1.90 & 1.22 & 1.34 \\
\hline S4 & 1.50 & 0.90 & 0.02 & 0.03 & 1.40 & 0.90 & 1.20 & 1.41 \\
\hline S5 & 2.90 & 3.70 & 2.30 & 2.61 & 0.20 & 0.22 & 0.41 & 0.74 \\
\hline S6 & 1.20 & 1.60 & 1.40 & 1.84 & 0.40 & 0.70 & 0.92 & 1.21 \\
\hline S7 & 0.50 & 0.20 & 0.20 & 0.44 & 2.00 & 2.40 & 0.13 & 0.17 \\
\hline
\end{tabular}




\section{Chromium}

Chromium is mainly used in preparation of alloys such as stainless steel, in chrome plating and in metal ceramics. It is used in metallurgy to impart corrosion resistance and a shiny finish; and also as dyes and paints. For decorating the idols paints are used which is the main source of $\mathrm{Cr}$ during idol immersion. Usually $\mathrm{Cr}$ is negligible in the lake but after immersion it increases little bit although not significantly. During the present investigation, highest concentration of copper was observed at $\mathbf{S} 5$ station during the post monsoon period while the minimum concentration was observed at $\mathbf{S} 4$ station during the pre monsoon period. It can be concluded from the above observations that although chromium is used in paints but its concentration does not increase significantly even after idol immersion. The S4 sampling station which is free from such activities showed minimum concentration of chromium in its samples. Dixit et.al. (2008) studied heavy metal pollution in Shahpura Lake Bhopal and concluded that $\mathrm{Cu}, \mathrm{Cr}, \mathrm{Pb}, \mathrm{Cd}$ and $\mathrm{Mn}$ were present in higher concentration as compared to their permissible limits. As an essential nutrient, chromium is bio accumulated by a variety of aquatic organisms (Moore et. al. , 1984). Water hardness, temperature and to some extent $\mathrm{pH}$ affect the bioaccumulation of chromium by aquatic organisms (Faust et.al., 1981).

\section{Mercury}

Mercury is a liquid metal that is used in cell batteries, fluorescent lights, switches and other control equipments. It has been well known as an environmental pollutant. It can enter water supply by industrial and consumer waste or even from acidic rain, breaking down soils and releasing heavy metals into streams, lakes, rivers and groundwater. Excess mercury in water can lead to loss of muscle control, kidney disease and brain damage. The observations of the present study indicate that maximum concentration of mercury is present at $\mathbf{S} 1$ sampling station during the post monsoon season whereas minimum concentration was present at $\mathbf{S} 5$ sampling station during the pre monsoon season. Organic compounds of mercury, for example methyl mercury when it enters the human body, concentrates in the brain and destroys the brain cells, damaging the central nervous system, and also causes corrosion and ulceration of the digestive tracts, Bowen H.J.M., 1996. Among the heavy metals, mercury is considered as the most dangerous pollutant to natural environment because of the ability of plants and animals to accumulate it (Porvari and Verta, 2003) and because of its detrimental effects even at very low concentrations (Nriagu, 1979).

\section{CONCLUSION}

Studies carried out in the present investigation revealed that the concentration of a few heavy metals, specifically increases in the post monsoon season that is actually the period after idol immersion. The concentration of lead, which is a chief constituent of paints used for decoration of idols showed a significant increase in the post monsoon period specifically at Prempura Ghat which is chiefly used for the purpose whereas other sampling sites were generally not much affected. An increase in the concentration of copper might be attributed to runoff water from the catchment areas nearby where use of chemical fertilizers is prevalent. Besides, the water quality in terms of heavy metal concentration is not worst although it is alarming and by adopting proper measurements it can be controlled.

\section{REFERENCES}

1. APHA American Public Health Association. Standard methods for the examination of water and wastewater, Washington D.C., $19^{\text {th }}$ edition, 1999.

2. Mukerjee, A., Religious activities and management of water bodies, Case study of idol immersion in context of urban lakes management. International Water History
Association, 3(3): (2005).

3. Vyas, Anju, Bajpai A, Verma N, and Dixit S. Heavy metal contamination cause of idol immersion activities in urban lake Bhopal, India. J. Appl. Sci. Environ Manage., 11(4) 37-39 (2007).

4. Jaswant Singh and Suraj K. Upadhyay studied Seasonal variations in Heavy 
Metals in Ramgarh Lake, Gorakhpur, India International Journal of Lakes and Rivers. ISSN 0973-4570, 5(2); 63-74 (2012).

5. Anilava Kaviraj, Das Satabadi. Effect of fertilization on the deposition, partitioning and bioavailability of cadmium, zinc and copper in four perennial ponds of an industrial town. Indian J Environ HIth, 44(1): 6-15 (1999). [22 Ref]

6. Namdev, G.R., Bajpai, A. and Malik, S. Studies on accumulation of micronutrients through run off in a potable water resource, Bhopal (M.P.). International Journal of Pharma and Bio Sciences. 2(3): 468-472 (2011b).

7. Dixit S. and Tiwari S. Impact assessment of heavy metal pollution of Shahpura lake, Bhopal. International Journal of Environmental Research , 2(1): 37-42 (2008).

8. Moore, James W. and Ramamoorthy, S. Heavy Metals in Natural waters: Applied Monitoring and Impact Assessment, Springer-Verlag; New York, 28 - 246 (1984).

9. Faust S.D., Aly O.S. Chemistry of Natural Waters. Butterworth, Woburn, Mass. Jain, P.C. Monika Jain 1999. Engineering Chemistry, $13^{\text {th }}$ edition. Dhanpat Rai Publishing Company (P) Ltd. New Delhi:29 - 31, (1981)

10. Bowen H.J.M., Trace element in Biochemical (New York: Academic Press Including) (1996).
11. Nriagu, J.O. (Ed.) The biochemistry of mercury in the environment. Elsevier/ North Holland Biomedical Press, Amsterdam, New York, Oxford (1979).

12. Porvari V. and Verta M., Total and methyl mercury concentration and fluxes from small boreal forest catchments in Finland. Environmental Pollution 123: 181-191 (2003).

13. Pravin U. Singare, Ravindra M. Mishra, Manisha P. Trivedi. Heavy Metal Pollution in Mithi River of Mumbai. Frontiers in Science , 2 (3): 28-36 (2012). DOI : 10.5923/j. fs. 20120203.03

14. Murehkar Gopalkrushna Haribhau, studied Trace metals contamination of surface water samples in and around Akot city in Maharashtra, India. Research Journal of Recent Sciences ISSN 2277-2502, 1(7): 5-9 (2012)

15. Choudhary R, Rawtani P, Vishwakarma M. Comparative study of Drinking Water Quality Parameters of three Manmade Reservoirs i.e. Kolar, Kaliasote and Kerwa Dam. Curr World Environ :6(1);145-149 (2011).

16. G.N. Tug and F. Duman. Heavy Metal accumulation in soils around a Salt Lake in Turkey. Pak. J. Bot., 42(4): 2327-2333, (2006). 